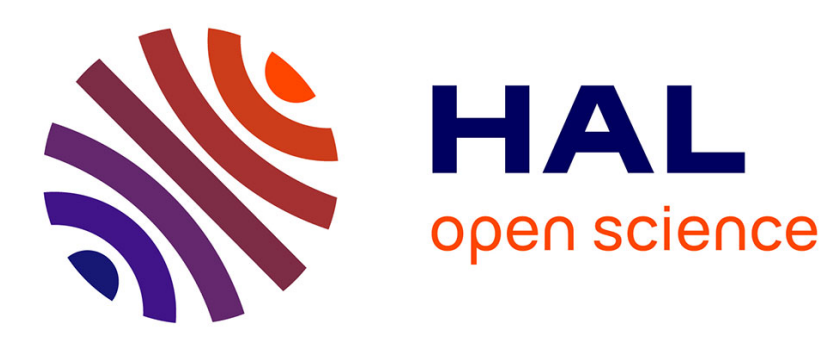

\title{
Tibetan Plateau summer monsoon northward extent revealed by measurements of water stable isotopes
}

\author{
L. Tian, V. Masson-Delmotte, M Stievenard, T. Yao, J. Jouzel
}

\section{To cite this version:}

L. Tian, V. Masson-Delmotte, M Stievenard, T. Yao, J. Jouzel. Tibetan Plateau summer monsoon northward extent revealed by measurements of water stable isotopes. Journal of Geophysical Research: Atmospheres, 2001, 106 (D22), pp.28081-28088. 10.1029/2001JD900186 . hal-03100013

\section{HAL Id: hal-03100013 https://hal.science/hal-03100013}

Submitted on 9 Feb 2021

HAL is a multi-disciplinary open access archive for the deposit and dissemination of scientific research documents, whether they are published or not. The documents may come from teaching and research institutions in France or abroad, or from public or private research centers.
L'archive ouverte pluridisciplinaire HAL, est destinée au dépôt et à la diffusion de documents scientifiques de niveau recherche, publiés ou non, émanant des établissements d'enseignement et de recherche français ou étrangers, des laboratoires publics ou privés. 


\title{
Tibetan Plateau summer monsoon northward extent revealed by measurements of water stable isotopes
}

\author{
L. Tian, ${ }^{1}$ V. Masson-Delmotte, ${ }^{2}$ M. Stievenard, ${ }^{2}$ T. Yao ${ }^{1}$, and J. Jouzel ${ }^{2}$
}

\begin{abstract}
A program of individual precipitation events and river water sampling and of water isotopic measurements $\left(\delta \mathrm{D}, \delta^{\mathrm{P}} \mathrm{O}\right)$ was carried out during summer 1996 along a northeast/southwest transect of the Tibetan Plateau. The spatial distribution of both $\delta^{18} \mathrm{O}$ and deuterium excess $\left(d=\delta D-8 * \delta \delta^{18} \mathrm{O}\right)$ of the precipitation reveals three distinct regions. Simulations with a simple isotopic model and seasonal isotopic variations measured at two extreme south and north locations support our interpretation in terms of different summer moisture origins: (1) South of the Himalayan mountains, the moisture provided by the Indian monsoon has been recycled over the Indian peninsula. (2) Between the Himalayas and the Tanggula mountains the oceanic moisture is directly transported from the Bay of Bengal along the Brahmaptra River valley. (3) North of the Tanggula mountains, the moisture is not provided by the monsoon anymore but by continental water recycling.
\end{abstract}

\section{Introduction}

The precipitation isotopic composition $\left(\delta \mathrm{D}, \delta^{18} \mathrm{O}\right)$ represents an integrated climatic parameter, reflecting the evaporation and condensation history of an air mass. The World Meteorological Organization/International Atomic Energy Agency (WMO/LAEA) network set up to monitor the global isotopic composition of the precipitation enables to define different moisture origins for Asian precipitation [Araguas-Araguas et al., 1998] but still lacks measurements in the Tibetan Plateau region. In particular, the limit between the Indian monsoon influence and the moisture transported by the westerlies remains uncertain. The difficulty to access such high-altitude sites strongly limits the ability to run continuous precipitation samplıng, especially during the monsoon season. However, high-altitude Tibetan glaciers offer unique archives of past tropical precipitation and several ice cores have already been successfully retrieved there [Thompson et al., 1989; Thompson et al., 1995]. To interpret past changes in precipitation isotopic composition, it is necessary to have a minimum knowledge of modern Tibetan Plateau precipitation isotopic composition seasonality and spatial distributions. The isotopic composition of the precipitation also offers an opportunity to distinguish between different water origins and therefore better define the northward limits of the monsoon influence. A network monitoring individual precipitation events was set up in Tibet in 1991. Some previous works have brought insight on local $\delta^{18} \mathrm{O}$ distribution in SeptemberOctober [Aizen et al., 1996, Wake and Stievenard, 1995] and on the $\delta^{18}$ O-temperature relationship [Yao et al., 1996; 1999].

Here we show results from isotopic measurements conducted during the summer 1996 monsoon season (May to

\footnotetext{
${ }^{1}$ Laboratory of Ice Core and Cold Regions Environment, Cold and Arid Regions Environmental and Engineering Research Institute, Lanzhou, China.

${ }^{2}$ Laboratoire des Sciences du Climat et de l'Environnement, Gif-surYvette, France.
}

Copyright 2001 by the American Geophysical Union.

Paper number 2001JD900186.

0148-0227/01/2001JD900186\$09.00
September) along a northwest/southeast transect of the Tibetan Plateau, across the Tanggula and the Himalayan mountains (Figure 1). Four locations have been chosen to perform individual precipitation sampling: three meteorological stations (Delingha, Tuotuohe, and Lhasa) and the bottom of Xixiabangma glacier during the 1996 summer glaciological fieldwork; in complement, water from the main rivers has also been collected, as well as fresh snow at Xixiabangma (Figure 1 and Table 1). The total precipitation amounts recorded at Nyalam (a meteorological station close to Xixiabangma glacier), Lhasa, Tuotuohe and Delingha are $566,584,278$, and $170 \mathrm{~mm}$, respectively, of water in 1996 . In the south these precipitations and their seasonal cycle reflect an average monsoon year except for Lhasa, 30\% above the multiyear average (Table 1 ).

In this paper we focus on the information brought by the precipitation isotopic composition. The $\delta^{18} \mathrm{O}$ and $\delta \mathrm{D}$ of the precipitation depend mainly on the degree of distillation of the air mass. They are related by the "global meteoritic water line," $\delta \mathrm{D}=8 \delta^{18} \mathrm{O}+10$ [Craig, 1961], where the slope of eight results from the differences in equilibrium fractionation coefficients for the two isotopes. In temperate and polar regions the degree of distillation is mainly driven by the progressive moisture depletion as the air masses move inland or cool down toward the poles. As a result, local spatial linear relationships can be empirically defined between surface temperature (a first-order indicator of rain-out degree, correlated to the cloud condensation temperature) and precipitation isotopic composition. In tropical regions the distillation of the air masses is strongly dependent on vertical movements due to convective activity. In this case the firstorder measurement of the degree of distillation is not the local surface temperature, which is not related to the condensation temperature but the precipitation amount.

Simulations performed with a simple isotopic model [Ciais et al, 1994] show the decrease of the slope between $\delta^{18} \mathrm{O}$ and surface temperature depending on the type of distillation (Figure 2). When a closed cloud is considered (all the condensed phase stays in the cloud, no precipitation), which is an idealized convectıve situation, this slope is much weaker than in the case of a classical Rayleigh distillation, where the 


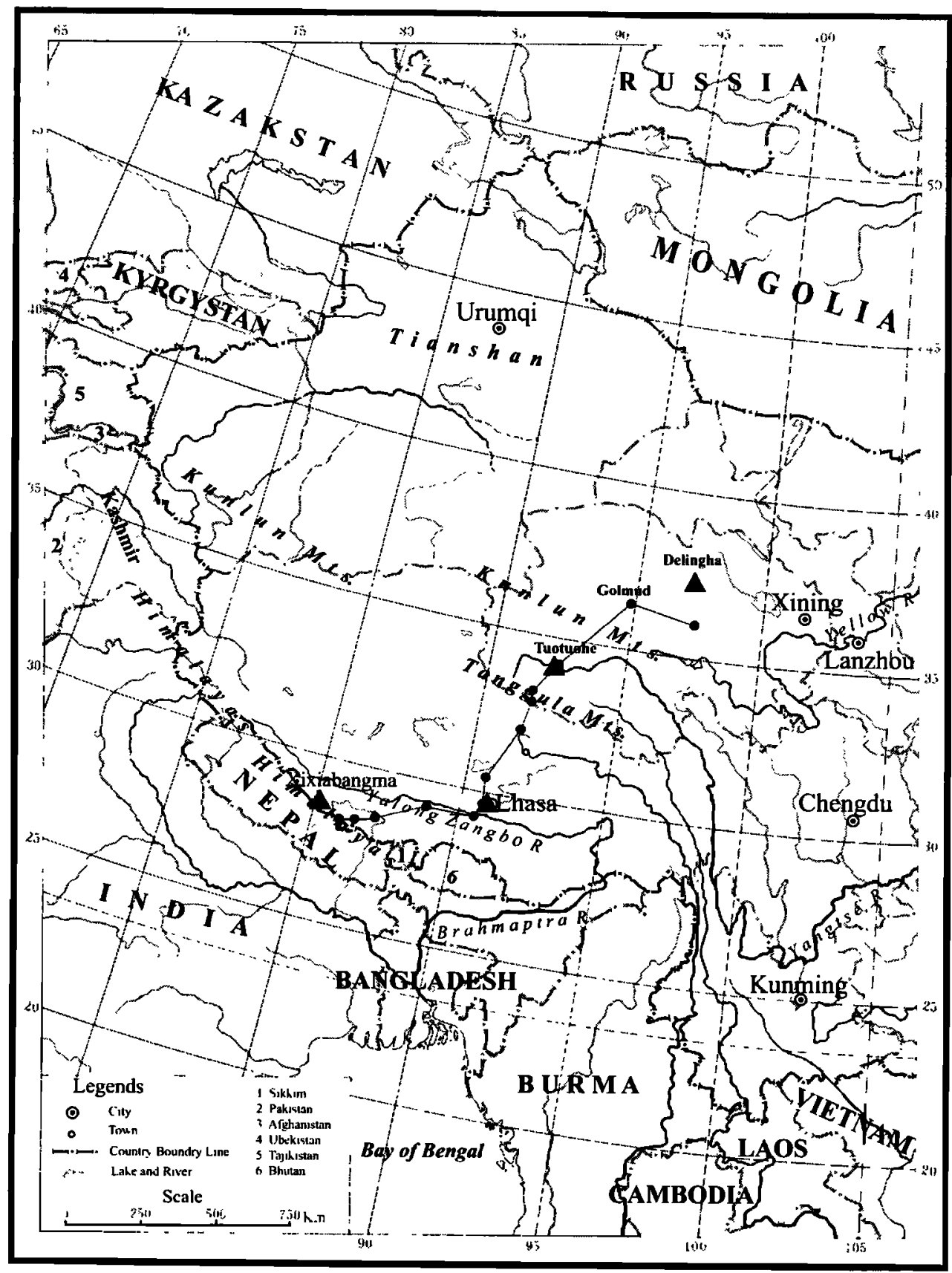

Figure 1. Geographic map of western China and surrounding countries showing the location of the precipitation sampling sites (triangles) and the river sampling sites (circles). The main mountain ranges are also indicated.

entire condensed phase is precipitated (open cloud). In the latter case, climatic conditions leading to droplet reevaporation below the cloud base (dry air) or moisture recycling at the land surface (dry ground before the rainfall) both result in higher $\delta^{18} \mathrm{O}$ values and weaker $\delta^{18} \mathrm{O}$ temperature slopes (Figure 2). As different phase change histories can result in similar $\delta^{18} \mathrm{O}$ behaviors, the first-order isotopic measurements are not sufficient to reconstruct air mass histories.

At the second order, slight differences between the two isotopes can arise during kinetic fractionation and justify using a second-order isotopic parameter, the deuterium excess $d=\delta \mathrm{D}-8 \delta^{18} \mathrm{O}$ [Dansgaard, 1964]. With a global mean average of 10 [Craig, 1961], $d$ varies both spatially and temporally [Rozanski et al., 1993]. The values of $d$ in the precipitation reflect the nonequilibrium fractionation occurring at the moisture initial evaporation from the ocean (depending on the speed of the evaporation, therefore on the air relative humidity, and the sea surface temperature) [Jouzel et al., 1982; Johnsen et al., 1989], at the land surface (when continental recycling is considered), and along the air mass trajectory (reevaporation of the droplets, formation of ice crystals). In particular, $d$ increases with the moisture source temperature (moisture source effect), increases at cold temperatures (snow formation effect). Simulations with a theoretical isotopic model (Figure 2) also show that $d$ 
Table 1. Characteristics of the Sampling Sites (Latitude, Longitude, Altitude, Annual Mean Air Temperature and Precipitation, Seasonality of the Precipitation Defined As the Ratio Between the Precipitation Falling Between May and September to the Annual Mean Precipitation) and of the Water Sampling (Period of Collection, Number of Samples, Average May-August Isotopic Values). ${ }^{a}$

\begin{tabular}{|c|c|c|c|c|c|}
\hline & Delingha & Tuotuohe & Rivers & Lhasa & Xixiabangma \\
\hline Latitude & $37.37^{\circ} \mathrm{N}$ & $34.21^{\circ} \mathrm{N}$ & $\begin{array}{l}36.41^{\circ} \mathrm{N} \text { to } \\
28.18^{\circ} \mathrm{N}\end{array}$ & $29.70^{\circ} \mathrm{N}$ & $28.45^{\circ} \mathrm{N}$ \\
\hline Longitude & $97.97^{\circ} \mathrm{E}$ & $96.43^{\circ} \mathrm{E}$ & $\begin{array}{l}97.70^{\circ} \mathrm{E} \text { to } \\
85.97^{\circ} \mathrm{E}\end{array}$ & $91.13^{\circ} \mathrm{E}$ & $85.78^{\circ} \mathrm{E}$ \\
\hline Altitude & $2981 \mathrm{~m}$ & $4533 \mathrm{~m}$ & & $3658 \mathrm{~m}$ & $5680 \mathrm{~m}$ \\
\hline Temperature & $3.7^{\circ} \mathrm{C}$ & $-3.8^{\circ} \mathrm{C}$ & & $7.5^{\circ} \mathrm{C}$ & $\begin{array}{l}\text { Nyalam }(3810 \mathrm{~m}) \\
3.5^{\circ} \mathrm{C}\end{array}$ \\
\hline Precipitation & $219.9 \mathrm{~mm}$ & $264.4 \mathrm{~mm}$ & & $444.8 \mathrm{~mm}$ & $\begin{array}{l}\text { Nyalam }(3810 \mathrm{~m}) \\
617.9 \mathrm{~mm}\end{array}$ \\
\hline Seasonality & $91 \%$ & $93 \%$ & & $98 \%$ & $64 \%$ \\
\hline Start of sampling & May 12,1993 & May 26, 1996 & July 13, 1996 & May 27, 1996 & July 29, 1996 \\
\hline End of sampling & Sept. 1, 1996 & August 28,1996 & July 23, 1996 & Aug. 23,1996 & August 15,1996 \\
\hline $\begin{array}{l}\text { Number of } \\
\text { samples }\end{array}$ & 112 & 49 & 13 & 59 & 25 \\
\hline $\begin{array}{l}\delta^{18} \mathrm{O} \\
d\end{array}$ & $\begin{array}{l}-6.5 \%( \pm 1.5 \%) \\
+11.8 \%\left( \pm 2.7 \%_{0}\right)\end{array}$ & $\begin{array}{l}-9.0 \% \\
+15.7 \%\end{array}$ & $\begin{array}{l}-14.8 \% 0 \\
+9.5 \%\end{array}$ & $\begin{array}{l}-16.8 \% 0 \\
+7.9 \%\end{array}$ & $\begin{array}{l}-19.2 \% \\
+17.9 \% 0\end{array}$ \\
\hline
\end{tabular}

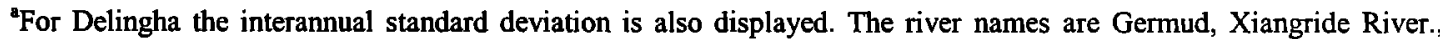
Tuotuohe, Yanshiping, Tanggula mountains., Amdo River, Dangxiong River, Lhasa River., Yarlungzangbo, Xigaze, Tingri, Lalong Pass, and Nyalam River.

increases when the moisture provides from continental recycling, or when a convective cloud is considered (closed cloud), while it decreases when droplet reevaporation takes place during the precipitation.

These theoretical studies support the use of $\left(\delta^{18} \mathrm{O}, d\right)$ values to constrain the origin of the moisture in continental regions such as the Tibetan Plateau.

\section{Measurements and Results}

Deuterium measurements were performed at the Laboratoire des Sciences du Climat et de l'Environnement, France, with an analytical precision of $1.0 \%$. The oxygen isotope composition of the 312 water samples was measured at the Laboratory of Ice core and Cold Regions Environment, Cold and Arid Regions Environmental and Engineering Research Institute, China, with a precision of $0.2 \%$. An intercalibration exercise conducted on $20 \%$ of Delingha $\delta^{18} \mathrm{O}$ samples measured in both laboratories has confirmed the analytical precision (mean of the differences of $0.06 \%$; mean absolute value of the differences of $0.11 \%$; standard deviation of the absolute values of the differences $0.08 \%$ ). The error on $d$ is evaluated as the quadratic average of the errors on $\delta \mathrm{D}$ and $8 \delta^{18} \mathrm{O}$, here about $1.9 \%$. For studies focusing on past variations in polar excess, the weak amplitude of the excess fluctuations (typically 5\% along a glacial-interglacial cycle, Vimeux et al. [1999]) required a higher analytical precision. However, the precision used here is enough to study the large spatial and temporal fluctuations shown by the excess of Tibetan precipitation (typically 10 to $20 \%$ ).

\subsection{Meteoric Water Line on the Tibetan Plateau}

The local meteoric water line calculated from individual precipitation events at each sampling site (Table 2) is generally close to the global value of 8 , with the highest slope at the most inland location (Delingha). To complement the precipitation data obtained at only four sampling sites, 13 large rivers (from Germud in the extreme north of the Tibetan

Table 2. Meteoritic Water Line Calculated During the Sampling Interval for Each Site.

\begin{tabular}{|c|c|c|c|}
\hline & Slope & Intercept & $\begin{array}{l}\text { Correlation } \\
\text { Coefficient } r^{2}\end{array}$ \\
\hline Delingha, 3 years & 8.4 & 15.0 & 0.98 \\
\hline May-August 1996 only & 8.3 & 13.5 & 0.98 \\
\hline Tuotuohe & 8.2 & 17.5 & 0.97 \\
\hline Lhasa & 7.9 & 6.2 & 0.97 \\
\hline $\begin{array}{l}\text { Xixiabangma precipitation at } 5900 \mathrm{~m} \\
\text { Fresh snow between } 6400 \text { and } 7000 \mathrm{~m}\end{array}$ & $\begin{array}{l}8.2 \\
8.7\end{array}$ & $\begin{array}{l}21.5 \\
29.9\end{array}$ & $\begin{array}{l}0.99 \\
0.99\end{array}$ \\
\hline Rivers & 8.4 & 16.5 & 0.99 \\
\hline
\end{tabular}



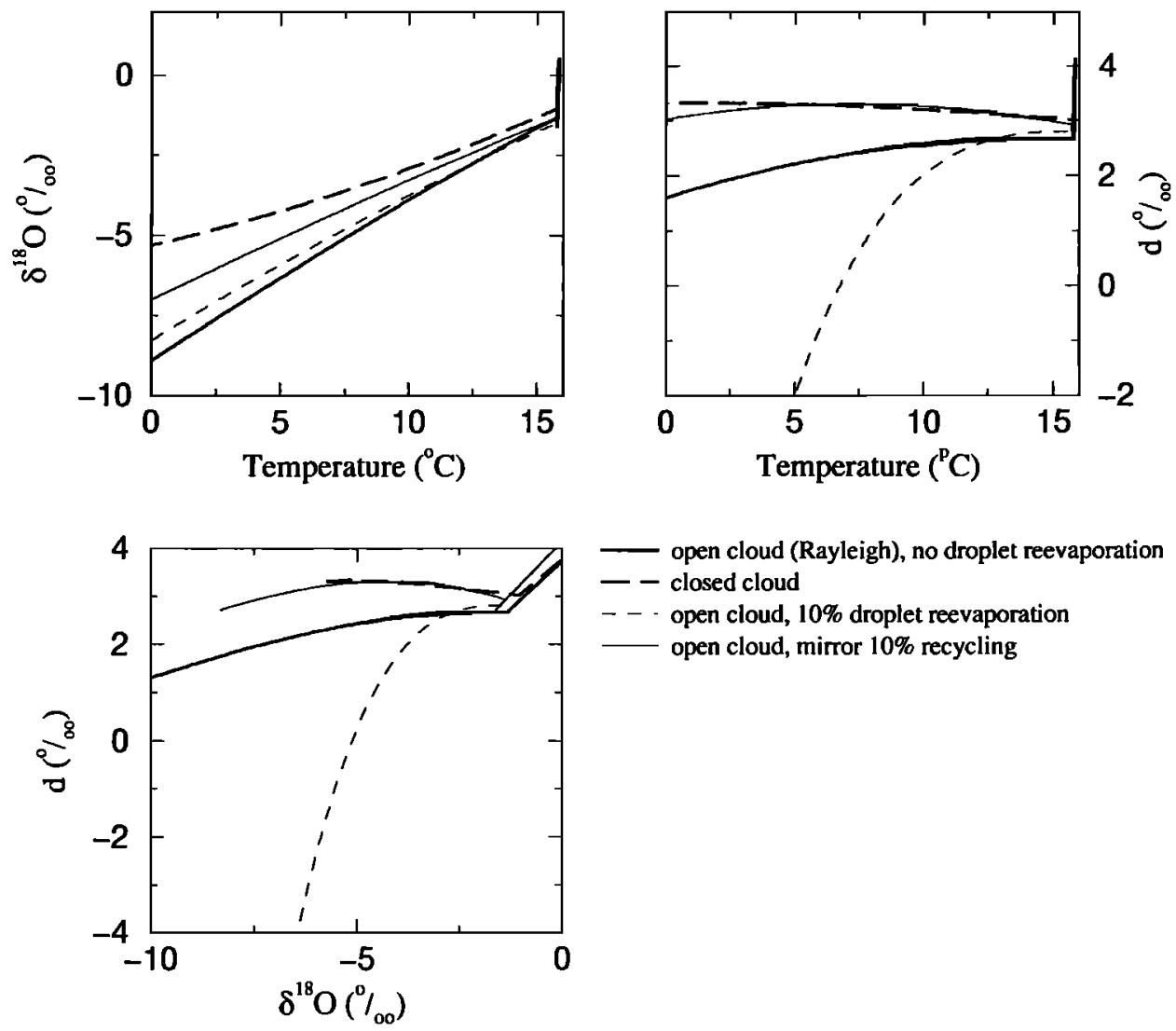

- open cloud (Rayleigh), no droplet reevaporation
-- closed cloud
-- open cloud, $10 \%$ droplet reevaporation
- open cloud, mirror $10 \%$ recycling

Figure 2. Variations of $\delta^{18} \mathrm{O}$ and $d$ simulated using the mixed cloud isotopic model from Ciais et a.l [1994] along trajectories from an ocean at $20^{\circ} \mathrm{C}$ until a condensation temperature of $0^{\circ} \mathrm{C}$ under different parameterizations to take into account the cloud type (open cloud, all the condensate leave the cloud; closed cloud, all the condensate remain inside) and the possible reevaporations (during the droplet fall or at the land surface). The closed cloud system (representative of convectıve clouds) and/or the mirror recycling (assuming no land reservoir) is associated with high $d$ values even with low temperatures. On the contrary, the droplet reevaporation leads to a large $d$ decrease. Note that the closed cloud system also results in a weaker dependency of $\delta^{18} \mathrm{O}$ on condensation temperature [Yao et al, 2000].

Plateau to Nyalam River in the southern slope of the Himalayas) were also sampled for water isotopes. In general, the river water isotopic composition results from combined effects of precipitation, evaporation, glacial meltwater, underground water, and plant transpiration. In most parts of the Tibetan Plateau, snow accumulation and ablation occur during summer, and the short residence time of snow explains that the glacial meltwater isotopic composition fits well with the precipitation isotopic composition. When the water balance is mainly controlled by precipitation, the stable isotopic composition of the rivers represents an integrated regional measurement of the precipitation. In our case, the $\delta \mathrm{D}-\delta^{18} \mathrm{O}$ slope obtained from the rivers $(8.4$, Table 2$)$ is close to the local meteoritic line and supports the use of the river data sets to complement the precipitation sampling network. The local $\delta \mathrm{D}-\delta^{18} \mathrm{O}$ slope being close to the global average of 8 justifies the use of the deuterium excess definition $d=\delta \mathrm{D}-8$ $\delta^{18} \mathrm{O}$ to extract the second-order isotopic information.

\subsection{Mean Summer 1996 Spatial Distribution of $\delta^{18} \mathrm{O}$ and $d$}

The spatial variations of the mean summer $1996 \delta^{18} \mathrm{O}$ of the precipitation (arithmetic average of all daily events) and river water samples are displayed in Figure 3 . The large spatial $\delta^{18} \mathrm{O}$ gradient (from $-5 \%$ in the north to $-20 \%$ in south Tibet) results from different isotopic processes. In the north the high isotopic composition of the precipitation mainly reflects the impact of high summer temperatures. On the contrary, the south Tibetan precipitation depleted isotopic composition is mainly influenced by the precipitation amount effect due to the heavy monsoon rains. It is not possible from the spatial $\delta^{18} \mathrm{O}$ distribution alone to delimit the respective extents of the monsoon influence versus the temperate climate influence, as its spatial fluctuations are quite smooth. The excellent agreement between the river water isotopic composition and the seasonal averages of precipitation supports, again, the use of the rivers to complement the information obtained at discrete precipitation-monitoring stations.

From north to south of the Tibetan Plateau, $d$ fluctuations are much more abrupt than the progressive decrease in $\delta^{18} \mathrm{O}$ values. Three different regions can be clearly defined from different $d$ levels in both precipitation and river samples: (1) north of the Tanggula mountains, $d$ has values above $11 \%$; (2) between the Tanggula and Himalayan mountains, $d$ decreases to about $7 \%$; (3) on the Himalayas, $d$ rises again to reach a maximum value at Xixiabangma $(17 \%)$. Even if the 


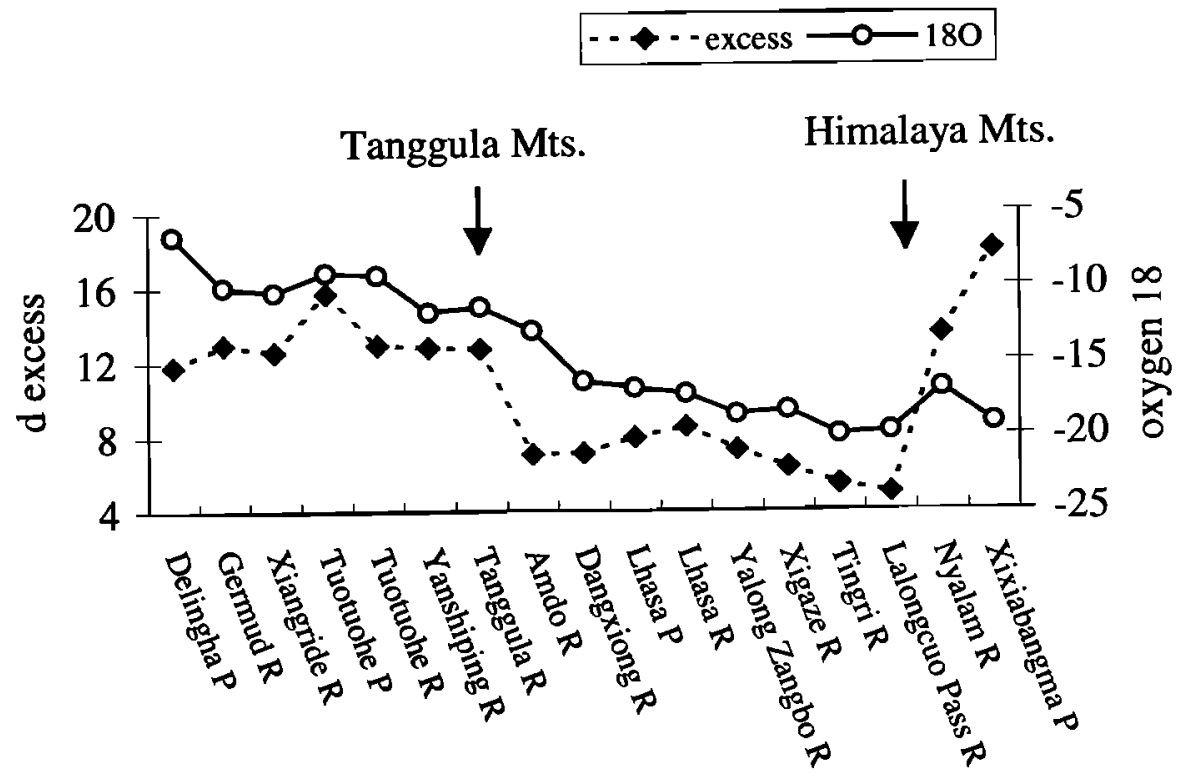

Figure 3. Geographical distribution of average summer 1996 isotopic composition of the precipitation from Delingha to Xixiabangma, combining precipitation and river water measurements.

precipitation sampling period is quite short at Xixiabangma (2 weeks), the measurements are representative of the local precipitation as indicated by $d$ values measured along a glacier snow pit at Dasuopu (7000 m), ranging between 14\%o and $20 \%$, with an average of $17.3 \%$. In glacier meltwater (at $5900 \mathrm{~m}$ ) which might represent an accumulation over several thousand years, $d(13.5 \%)$ is still much higher than at Lhasa.

The obvious difference of $d$ between the two sides of the Tanggula mountains is due to the limit between tropical and temperate air masses. North of the Tanggula mountains, high $d$ and $\delta^{18} \mathrm{O}$ in the precipitation are consistent with local summer convective precipitation occurring under dry climatic conditions and resulting from continental moisture recycling [Tian et al., 1996], with no direct inflow of oceanic air. Meteorological data (e.g., Figure 4) indeed locate the maximum northward extent of the Intertropical Convergence Zone in summer time close to the Tanggula mountains [Araguas-Araguas et al, 1998].

In the area between the Tanggula and the Himalayas, precipitation is directly controlled by the southwest Indian

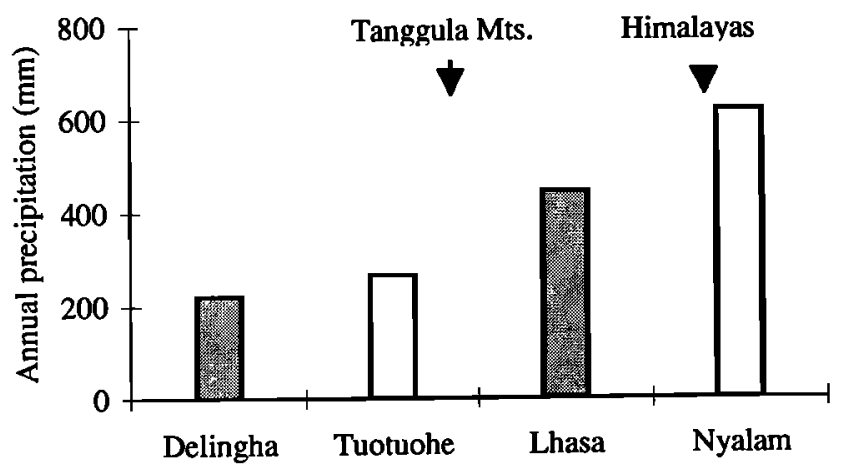

Figure 4. Annual precipitation at the four stations on the Tibetan Plateau. Annual precipitation is much higher in the south of the Tibetan Plateau due to the summer monsoon precipitation. monsoon. During the monsoon season, the molsture evaporated in the Bay of Bengal will move along the Brahmaputra-Yalongzangbo Rivers and bring rich precipitation in the south part of the Tibetan Plateau [Gao et al., 1985; Lin et al., 1990]. The moisture being transported directly from a nearby sea leads to low $d$ in the precipitation in south Tibet. This study also indicates that the southeast monsoon cannot pass the orographic barrier of the Tanggula mountains, at least in 1996.

The difference in $d$ between the two sides of the Himalayas also indicates different moisture origins. Two kinds of water trajectories reaching the Tibetan Plateau from the south have been evidenced [Lin et al., 1990]: (1) to the east, humid marine air mass from the Bay of Bengal, moving along the Brahmaputra-Yalongzangbo Rivers and reaching in the south of the Tibetan Plateau. Along this valley trajectory, large precipitation amounts are released due to the uplift of humid air masses, resulting in low $d$ (no significant land recycling) and low $\delta^{18} \mathrm{O}$ (depletion due to intense convection). (2) To the west, another trajectory can bring moisture from the Indian Ocean, over the Indian peninsula towards the southern slope of the Tibetan Plateau. In this case, the evaporation from the surface of the peninsula (with low relative humidity) can modify the initial marine air mass and result in high $d$ in the following precipitation (Figure 2). Another possible reason for the high $d$ in the Himalayas is the high-altitude precipitation associated with low cloud temperature. Simultaneous precipitation sampling at different levels may help better understand a possible altitude-deuterium excess relationship.

Atmospheric general circulation models fitted with the explicit modeling of water isotopes [Jouzel et al., 1987; Hoffmann et al., 1998] simulate unusually high annual mean $d$ values in central Eurasia (including the Tibetan Plateau), at places where in summer more than $50 \%$ of the simulated precipitation provides from continental recycling [Koster et al., 1993; Joussaume et al., 1986]. Although their spatial 


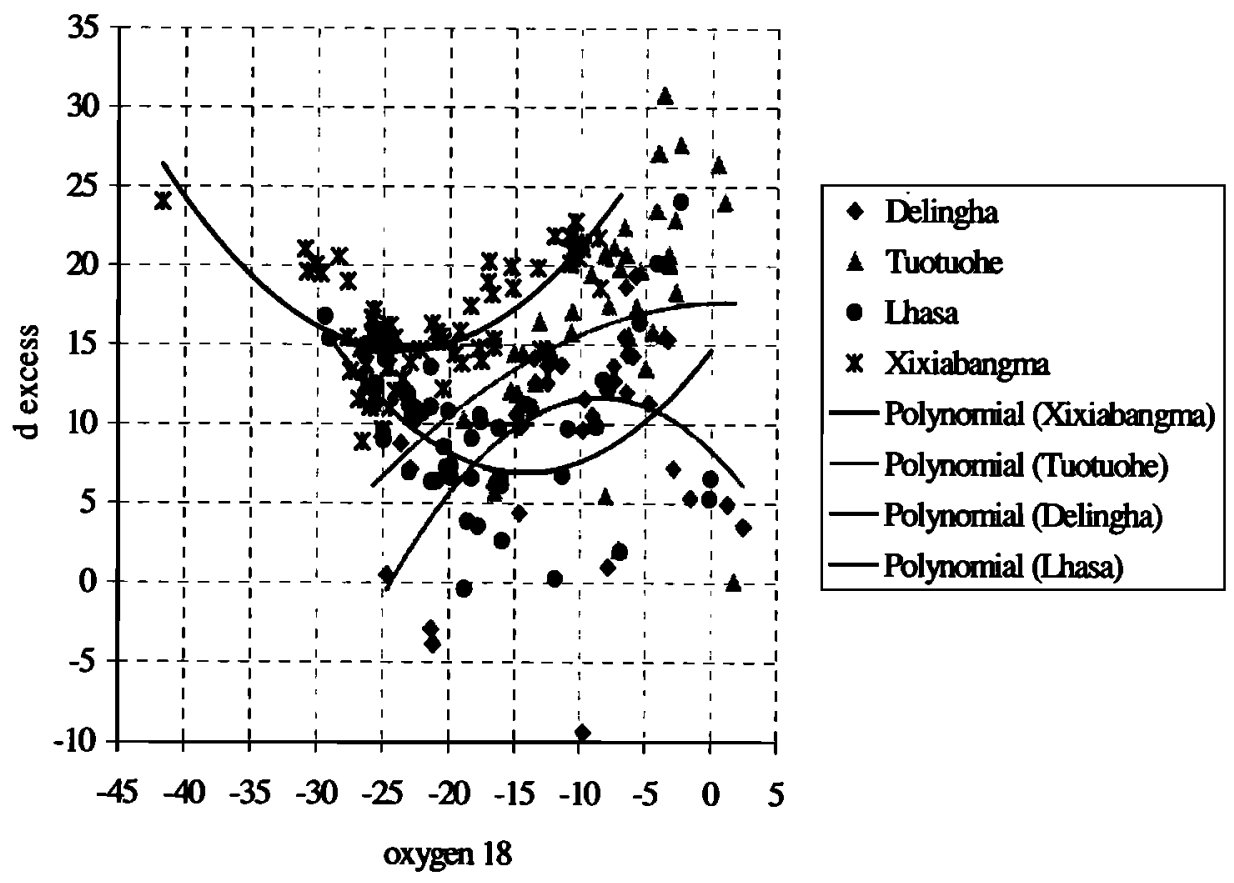

Figure 5. Temporal variations of $d$ with respect to $\delta^{18} \mathrm{O}$ in the four precipitation sampling sites.

resolution strongly limits their ability to capture synoptic climate processes, such broad-scale model results seem to confirm the role of continental moisture recycling in producing high excess levels in northern Tibet.

\subsection{Summer 1996 Temporal Relationships Between $d$ and $\delta^{10} \mathrm{O}$}

The day-to-day $\delta^{18} \mathrm{O}-d$ fluctuations undergo large and complex fluctuations which are difficult to interpret without many simultaneous local and large-scale meteorological observations. Therefore we only discuss here the relationships between $d$ and $\delta^{18} \mathrm{O}$ observed for the full monitoring period, starting from south to north (Figure 5).

Xixiabangma snowfall shows the most negative $\delta^{18} \mathrm{O}$ values, due to both the strong precipitation amount effect in the monsoon region and the very low air temperature in high altitude (Table 1); at this location, $d$ is very stable with high values (typically $20 \%$ ). When $\delta^{18} \mathrm{O}$ decreases below $-22 \%$, as a result from either very strong precipitation or long-distance moisture transport, $d$ is anticorrelated and increases. This may be due to a warmer oceanic moisture source or to a behavior specific to closed clouds. Indeed, depleted isotopic values are associated with strong monsoon activity and deep convection, bringing water vapor to very high altitudes. On the opposite, when $\delta^{18} \mathrm{O}$ increases above $-22 \%$ (weak precipitation intensity), $d$ also increases slightly, which may result from a larger proportion of moisture provided by continental recycling. Interestingly, atmospheric general circulation models indeed simulate high $d$ in summer over Tibet and central Asia, at places where they evaluate the proportion of recycled moisture to account for more than $50 \%$ of the total precipitation [Hoffmann et al., 1998; Koster et al., 1993].

At Lhasa, the rainfall exhibits a similar isotopic behavior to Xixiabangma, with a clear minimum in $d$ corresponding to $\delta^{18} \mathrm{O}$ values around $-15 \%$. Again, the strong monsoon activity accounts for depleted isotopic values and increasing $d$ levels, which remain, however, significantly lower than at Xixiabangma (see previous section). A significant proportion of the precipitation events are characterized by high $\delta^{18} \mathrm{O}$ values (above $-10 \%$ ) and a wide range of $d$ levels. This large dispersion results at least partly from local storms in the Lhasa valley, and the high $\delta^{18} \mathrm{O}$ values probably result from two different processes: (1) droplet reevaporation under very dry conditions (very low $\boldsymbol{d}$ values, associated with very little rainfall) or (2) moisture provided by inland continental recycling (very high $d$ values).

Tuotuohe has less depleted $\delta^{18} \mathrm{O}$ precipitation and higher $d$ values than the southem sites. Here $d$ increases with $\delta^{18} \mathrm{O}$, probably reflecting an increasing contribution from continental moisture. Even if the local climate is quite dry, only very few precipitation events have low $d$ values. Apart from these specific events, the cold local temperature may prevent frequent droplet reevaporation.

In summer 1996, Delingha (Figure 5) precipitation mainly reflects the summer temperatures with relatively high $\delta^{18} \mathrm{O}$ values compared to the other sites studied here. Note that Delingha is located north of the Kunlun Range, rather open toward the Tarim. When precipitation occurs there in the early spring at cold temperatures, low $\delta^{18} \mathrm{O}$ values are associated with low excess levels, maybe due to droplet reevaporation under dry conditions. This is also the case for several shallow rain events associated with very high $\delta^{18} \mathrm{O}$ values (between -5 and $+5 \%$ ) and low $d$ values.

\subsection{Seasonal $d$ Cycles at Delingha and Lhasa}

For Delingha, 3 years of observations are available, which enables to obtain a first estimate of the mean seasonal isotopic cycle (Figure 6a). The $\delta^{18} \mathrm{O}$ cycle clearly shows that Delingha is outside of the monsoon influence and mainly reflects the seasonal air temperature cycle with minimum 


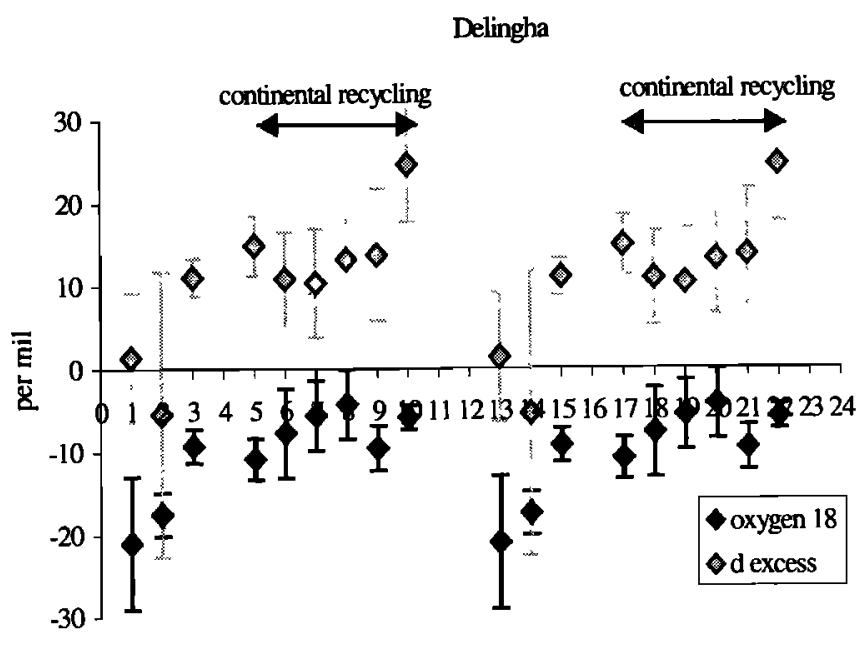

Lhasa

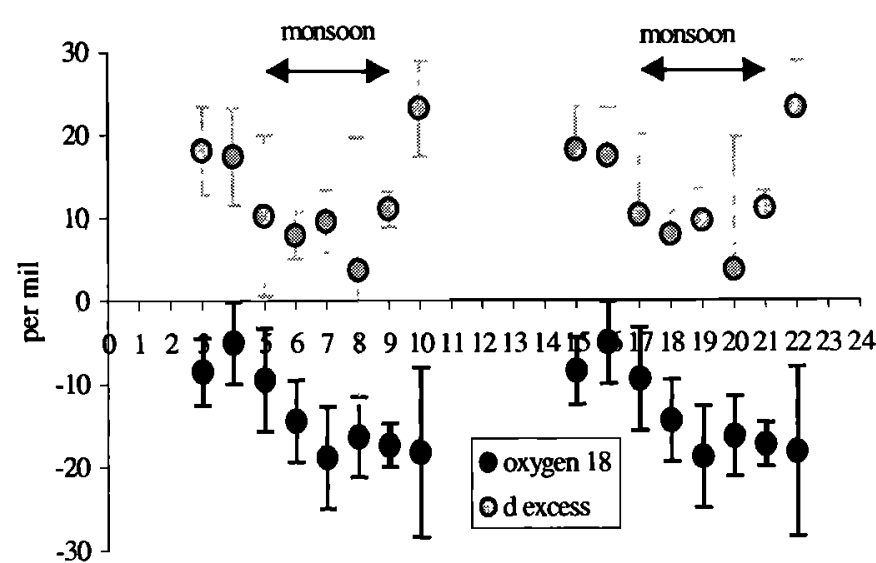

Figure 6. (a) Mean seasonal variations in precipitation isotopic composition at Delingha for 1993-1996. Monthly averages and standard deviations are calculated as the mean of daily data (months with only one precipitation event are not displayed). (b) Same as Figure 6a but for Lhasa (1986 to 1991) IAEA/WMO monthly measurements.

values in December-January and high values between June and October. Because of the very dry climate (about 200 $\mathrm{mm} / \mathrm{yr}$, Table 1), some months undergo only very few precipitating events even over 3 years of observations (February to April and October to December). The $d$ seasonal cycle is therefore somehow biased toward individual rainfall values, with negative levels in February and April as a result of droplet reevaporation under dry conditions. Nevertheless, it is obvious that Delingha is characterized by a maximum $d$ in summer and autumn, unlike most Northern Hemisphere stations [Rozanski et al, 1993]. The extreme continentality of Delingha location may be responsible for such high $d$ values and almost positive $\delta^{18} O$ in late summer, due to inland moisture recycling toward Delingha. This result is supported by IAEA data obtained at Hetian, located at the same latitude as Delingha but at the extreme west of China. A similar seasonality is also observed in water isotope records measured along an east Mongolian ice core [Schotterer et al., 1997], suggesting common processes in central Asia. Such a continental effect could account for the high dependency of precipitation $\delta^{18} \mathrm{O}$ on local temperature in central Asia evidenced by recent studies [Tian et al., 1996; Yao et al., 1999].

For comparison, $d$ and $\delta^{18} \mathrm{O}$ in Lhasa precipitation show quite different seasonal variations (Figure 6). Before and after the monsoon season, $d$ and $\delta^{18} \mathrm{O}$ are quite high due to the continental moisture origin, as in Delingha. However, the strong Indian monsoon precipitation from June to September results in very low $\boldsymbol{d}$ in precipitation, modifying completely the seasonal cycle. Similar characteristics have also been observed during the Pacific monsoon in southeast China [ $\mathrm{Wei}$ and Lin, 1994].

\section{Conclusions}

Our data have significantly increased the density of precipitation isotopic composition data in the Tibetan Plateau region. We have shown the interest of the deuterium excess parameter as a tool to delimit the northward extent of the Indian monsoon.

The characteristics of stable isotopes in precipitation to the north of the Tibetan Plateau represent the common condition of stable isotopes in precipitation in the inland of Asia where the climate is dry and the local hydrological cycle is predominant. Our data confirm previous results obtained with general circulation models, suggesting that the high continentality inland Asia (more than $50 \%$ of the precipitation being recycled over the continent) results in high summer $\delta^{18} \mathrm{O}$ and $d$ in precipitation. Our study also reveals that in this area beyond the monsoon influence, stable isotopes are mainly influenced by temperature, which provides a basis for the reconstruction of paleoclimate information from future ice core retrieved in the Asian interior.

The high-altitude precipitation data obtained here seem to indicate that the excess increase at cold temperatures is not limited to the polar regions. High $d$ values in the high Himalayas can also be partly ascribed to the closed cloud isotopic behavior of deeply convective clouds at low temperature and high altitude (Xixiabangma glacier). This result supports the need for further precipitation and water vapor sampling at various altitudes along a common moisture trajectory.

Our data provide a first spatial-temporal framework, which will be useful to interpret past $d$ fluctuations measured along Tibetan ice cores. Pursuing the collection network over several years will help relate the isotopic composition of the precipitation to the moisture origin under different monsoon configurations (El Niño or $\mathrm{La}$ Niña situations). Past fluctuations of $d$ have recently been measured along ice cores drilled in the mid-Himalayas [Thompson et al, 2000]. For the interpretation of such fluctuations, a better understanding of the relationship between $d$ in precipitation and monsoon activity is required and can be achieved only by means of modern precipitation monitoring.

Acknowledgments. This work is supported by the Chinese National Basic Research Program (G1998040802), Chinese Academy of Sciences (KZCX2-301), Innovation project of Cold and Arid Regions Environmental and Engineering Research Institute, CAS (CACX210506 and CACX 210046). Our thanks are given to all the persons involved in the precipitation sampling. We especially thank engineer $O$. Cattani for helping in the measurement of $\delta D$ and engineer Sun Weizhen for helping in the measurement of $\delta^{18} \mathrm{O}$. This is LSCE contribution 0533. 


\section{References}

Aizen, V., H. Aizen, J. Melack, and T. Martma, Isotopic measurements of precipitation on central Asian glaciers (southeastern Tibet, northern Himalayas, central Tian Shan), $J$. Geophys. Res., 101, 9185-9196, 1996.

Araguas-Araguas, L, K. Froehlich, and K. Rozanski, Stable isotope composition of precipitation over southeast Asia. J. Geophys. Res., 103, 28,721-28,742, 1998.

Ciais, P. and J. Jouzel, Deuterium and oxygen 18 in precipitation: Isotopic model, including mixed cloud processes, $J$. Geophys. Res., 99, 16,793-16,803, 1994

Craig, H., Isotopic variations in meteoric waters, Science, 133, 1702 $0703,1961$.

Dansgaard, W., Stable isotope in precipitation, Tellus, 14, 436-468, 1964.

Gao, D., H. Zou and W. Wei, Influence of water vapor pass along the Yarlungzangbo River on precipitation, (in Chinese with English abstract), Mount. Res., 3, 239-249 1985.

Hoffmann, G., M. Werner, and M. Heimann, Water isotope module of the ECHAM atmospheric general circulation model: A study on timescales from days to several years, J. Geophys. Res., 103, 16,871-16,896, 1998

Johnsen, S.L., W. Dansgaard, and J.W.C. White, The origins of Arctic precipitation under present and glacial conditions, Tellus, $41,452-468,1989$.

Jouzel, J., and L. Merlivat, Deuterium and oxygen-18 in precipitation: modeling of the isotope effects during snow formation. J. Geophys. Res. 89, 11,749-11,757, 1984.

Jouzel, J, L Merlivat, and C Lorius, Deuterium excess in an East Antarctic ice core suggests higher relative humidity at the oceanic surface during the last glacial maximum. Nature, 299, 688-691, 1982.

Jouzel, J., G. L . Russell, R. J. Suozzo, R. D. Koster, J. W. C. White, and W. S. Broecker, Simulations of the HDO and $\mathrm{H}_{2}{ }^{18} \mathrm{O}$ atmospheric cycles using the NASA GISS general circulation model: the seasonal cycle for present-day conditions, $J$. Geophys. Res., 192, 14,739-14,760, 1987.

Joussaume, S., R. Sadoumy and C. Vignal, Origin of precipitating water in numerical simulation of the July climate, Ocean Atmos. Interactions, $1,43-56,1986$.

Koster, R.D, D. Perry, and J. Jouzel, Continental water recycling and H218O concentrations, Geophys. Res. Lett., 20, 2215-2218, 1993.

Lin, Z., and X. Wu. A preliminary analysis about the tracks of moisture transportation on the Qinghai-Xizang Plateau, (in Chinese with English abstract), Geogr. Res., 9, 30-49 1990.

Rozanski, K., L. Araguas-Araguas, and R. Gonfiantini, Isotopic patterns in modern global precipitation, Climate Change in
Continental Isotopic Records, Geophys. Monogr. Ser., edited by P.J. Wart, K.C. Lohman, J. MacKenzie, and S. Savin, pp. 1-37, Washington D.C., 1993.

Schötterer, U., K. Frohlich, H W Gaggeler, S Sandjordj, and W Stichler, Isotope records from Mongolian and Alpine ice cores as climate indicators. Clim. Change, 36, 519-530, 1997.

Tian, L., T. Yao, and Z. Yang, $\delta^{18} \mathrm{O}$ in precipitation and moisture sources upon the Tibetan Plateau, Crysphere, 21, 33-39, 1996.

Thompson, L.G., et al., Holocene-late Pleistocene climatic ice core records from Qinghai-Tibetan Plateau, Science, 246, 474-477, 1989.

Thompson, L.G., et al., A 1000 year ice core climatic record from the Guliya Ice Cap, China, and its relationship to global climate variability, Ann. Glacio., 2I, 165-181, 1995.

Thompson, L.G., et al., A high -resolution millenial record of the South Asian monsoon from Himalayan ice cores, Science, 289, 1916-1919, 2000.

Vimeux, F., V. Masson, J. Jouzel, M. Stievenard, and J.R. Petit, Glacial-interglacial changes in ocean surface conditions in the southem hemisphere, Nature, 122, 1949-1970, 1999.

Wake, C., and M. Stievenard, The amount effect and oxygen isotope ratios recorded in Himalayan snow, in Paleoclimate and Environmental Variability in the Austral-Asian transect during the past 2000 years, pp. 236-241, Int. Geosphere-Biosphere Program, Nagoya, Japan, 236-241, 1995.

Wei, K., and R. Lin, The influence of the monsoon climate on the isotopic composition of precipitation in China, (in Chinese with English abstract), Geochimica, 23(1), 33-41, 1994

Yao, T., L.G. Thompson, E. Mosley-Thompson, Y.Zhihong, Z. Xingping, and P.-N. Lin, Climatological significance of $\delta^{18} \mathrm{O}$ in north Tibetan ice cores, J. Geophys. Res., 101, 29,531-29,537, 1996.

Yao, T., et al., Relationship between $\delta^{18} \mathrm{O}$ in precipitation and surface air temperature in the Urumqi River Basin, East Tianshan Mountain, China, Geophys. Res. Lett., 26(23), 3473-3480, 1999.

L. Tian and T. Yao, Laboratory of Ice Core and Cold Regions Environment, Cold and Arid Regions Environmental and Engineering Research Institute, Lanzhou, 730000 China.

J. Jouzel, V. Masson-Delmotte and M. Stievenard, J. Jouzel, IPSL/Laboratoire des Sciences du Climat et de l'Environnement, UMR CEA-CNRS 1572, CEA Saclay, 91191 Gif-sur-Yvette Cédex, France. (valerie.masson@cea.fr.)

(Received August 31, 2000; revised January 4, 2001; accepted January 17,2001 .) 